\title{
Pemodelan Multivariate Adaptive Regression Spline (MARS) Pada Faktor-Faktor yang Mempengaruhi Kemiskinan di Provinsi Maluku dan Maluku Utara
}

\author{
M. Y. Matdoan (1), S. N. Aulele ${ }^{(2)}$, Y. W. A. Nanlohy ${ }^{(3)}$ \\ Program Studi Statistika, Fakultas MIPA, Universitas Pattimura \\ Jln. Ir. M. Putuhena, Kampus Unpatti - Poka, Ambon, 97233, provinsi Maluku, Indonesia \\ e-mail: *yahya.matdoan@fmipa.unpatti.ac.id
}

\begin{abstract}
ABSTRAK
Penanggulangan kemiskinan di Provinsi Maluku dan Maluku Utara masih belum maksimal, hal ini karena masih terjadi peningkatan kemiskinan di daerah tersebut. Penelitian ini bertujuan untuk mengetahui faktor-faktor apa saja yang mempengaruhi kemiskinan di Provinsi Maluku dan Maluku Utara. MARS merupakan salah satu metode klasifikasi yang mampu menangani data ber-dimensi tinggi dengan pola data yang tidak diketahui sebelumnya, serta dapat diterapkan untuk melihat interaksi di antara variabel yang digunakan. Penelitian ini diperoleh hasil bahwa model MARS terbaik dengan kombinasi $\mathrm{BF}=39, \mathrm{MI}=3$ dan $\mathrm{MO}=1$ dan GCV sebesar 0.1728. Adapun variabel yang berpengaruh secara signifikan terhadap kemiskinin di Provinsi Maluku dan Maluku Utara yaitu variabel persentase lapangan pekerjaan kepala rumah tangga, persentase rumah tangga yang menggunakan jenis atap, persentase rumah tangga yang tidak menggunakan dinding tembok, persentase fasilitas penerangan yang digunakan, persentase penduduk yang sakit tetapi tidak berobat karena tidak memiliki biaya untuk berobat, persentase pendidikan terakhir kepala keluarga yang tidak/belum pernah sekolah dan persentase rumah tangga yang tidak memiliki fasilitas air minum.
\end{abstract}

Kata kunci : MARS, GCV, Kemiskinan, Provinsi Maluku, Provinsi Maluku Utara.

\section{ABSTRACT}

Poverty alleviation in the province of Maluku and North Maluku are still not optimal, this is because there is still an increase in poverty in the area. This study aims to determine what factors influence poverty in Maluku and North Maluku Provinces. MARS is one of the classification methods that are able to handle high-dimensional data with data patterns that are not previously known, and can be applied to see the interaction between the variables used. This research shows that the best MARS model with a combination of $B F=39, M I=3$ and $M O=1$ and Minimum $G C V$ of 0.1728. The variables that significantly influence poverty in the provinces of Maluku and North Maluku are the percentage of employment oppor-tunities for household heads, the percentage of households using roof types, the percentage of households that do not use wall walls, the percentage of lighting facilities used, the percentage of the population who are sick but do not seek treatment because they do not have the costs for treatment, percentage of last education of family heads who never attended school and the percentage of households that do not have drinking water facilities.

Keywords : MARS, GCV, Poverty, Maluku Province, North Maluku Province.

\section{PENDAHULUAN}

Kemiskinan saat ini masih menjadi masalah mendasar dimana aspek-aspek penting seperti ketersediaan kebutuhan pokok menjadi faktor krusial dan dalam kehidupan sehari-hari. Dampak akibat kemiskinan yaitu penggangguran yang semakin meningkat, mahalnya biaya pendidikan dan kesehatan, serta maraknya kekerasan dan konflik sosial yang bernuansa SARA di berbagai daerah. (Dedefo, et.al.,2020)

Provinsi Maluku merupakan salah satu provinsi di Indonesia Timur yang berada pada urutan ke-4 provinsi dengan persentase penduduk miskin tertinggi di Indonesia. Persentase penduduk miskin di Provinsi Maluku pada tahun 2019 yaitu sebesar 17.69\%, setelah Provinsi Papua sebesar 27.53\%, Provinsi Papua Barat sebesar 22.17\% dan Provinsi Nusa Tenggara Timur sebesar 21.09\% (BPS Provinsi Maluku, 2019). Selain Provinsi Maluku, provinsi Maluku Utara merupakan salah satu provinsi dari enam provinsi di Indonesia yang mengalami peningkatan persentase penduduk miskin yaitu sebesar 0.15 persen (BPS. Provinsi Maluku Utara, 2019). 
Menurut Badan Pusat Statistik (BPS) terjadi peningkatan jumlah penduduk miskin di Provinsi Maluku dari 317690 orang pada Maret 2019 menjadi 319510 pada September 2019. Jika dirataratakan maka terjadi penambahan 10 penduduk miskin setiap hari di Provinsi Maluku. Sementara itu, jumlah penduduk miskin di Provinsi Maluku Utara pun cenderung terus mengalami peningkatan, pada September 2019 penduduk miskin di Provinsi Maluku Utara sebanyak 87.18 ribu jiwa, mengalami peningkatan 2.6 ribu jiwa dibandingan dengan bulan Maret 2019. Hal ini menunjukan bahwa program penuntasan kemiskinan yang dilakukan oleh pemerintah di kedua provinsi belum maksimal. Oleh karena itu, perlu dikaji secara mendalam faktor-faktor apa saja yang mempengaruhi kemiskinan di Provinsi Maluku dan Maluku Utara (Matdoan M.Y, et.al., 2020).

Analisis regresi merupakan suatu metode statistika yang umum digunakan untuk melihat pengaruh antara variabel prediktor terhadap variabel respon (Bilski, P. 2020). Dalam menjelaskan pola hubungan antara variabel respon dengan variabel prediktor serta untuk mengestimasi kurva regresi dapat digunakan pendekatan regresi parametrik dan regresi nonparametrik (Budiantara, I. 2014).

Dalam regresi parametrik, diasumsikan bentuk kurva regresi diketahui (seperti linier, kuadratik, kubik). Namun, tidak semua pola hubungan dapat dilakukan dengan pendekatan parametrik, karena tidak adanya suatu informasi mengenai bentuk hubungan variabel respon dan variabel prediktor (Nuraziza, et., 2014). Jika asumsi model parametrik tidak terpenuhi maka kurva regresi dapat dilakukan dengan menggunakan pendekatan model regresi nonparametrik. Hal ini karena metode regresi nonpatametrik memiliki fleksibilitas yang tinggi dalam mengestimasi kurva regresi (Matdoan M.Y, et.al., 2020).

Keterbatasan informasi, bentuk fungsi, dan tidak jelasnya pola hubungan antara variabel respon (persentase kemiskinan) dengan faktorfaktor yang diduga mempengaruhinya, sehingga digunakan pendekatan regresi nonparametrik. Dalam pendekatan regresi nonparametrik secara adaptive banyak diminati. Salah satu contohnya adalah Regression Tree, Recursive Partitioning Regression (RPR) dan MARS.

Metode MARS memiliki kelebihan untuk mengatasi permasalahan data berdimensi tinggi (curse of dimensionality) serta mengatasi kelemahan RPR untuk menghasilkan model yang kontinu pada knot. Metode ini diperkenalkan oleh Friedman (1991), metode ini merupakan metode regresi nonparametrik yang mengasumsikan bentuk fungsi hubungan antara variabel respon dan prediktor tidak diketahui. Metode ini disusun berdasarkan beberapa koefisien fungsi basis, yang secara keseluruhan dikendalikan pada data (Kishartini, et.,al, 2014).

Beberapa hal yang perlu diperhatikan dalam metode MARS yaitu (Leathwick, J.R.et.el., 2006).

\section{a. Fungsi Basis}

Fungsi basis merupakan kumpulan dari fungsi yang digunakan untuk menjelaskan hubungan antara variabel respon dengan variabel prediktor. Fungsi basis merupakan fungsi par metrik yang didefinisikan pada setiap garis regresi (region). Maksimum fungsi basis (BF) yang diperbolehkan yaitu 2 sampai 4 kali dari jumlah variabel prediktor.

\section{b. Knot}

Knot dapat didefinisikan sebagai akhir dari sebuah region dan awal dari region yang lain. Hasil akhir diharapakan adanya kontinuitas fungsi basis diantar region satu dengan region yang lainnya. Minimum jarak antar knot atau minimum observasi antara knot (MO) sebesar 0, 1, 2, dan 3.

\section{c. Interaksi}

Interaksi merupakan cross product antar variabel yang saling berkorelasi. Friedman (1991) membatasi nilai maksimum interaksi (MI) adalah 1, 2, dan 3. Jika lebih dari 3 interaksi, maka akan menimbulkan intrepretasi model yang sangat kompleks.

Model MARS menurut Friedman ditulis dalam persamaan berikut :

$$
f(x)=a_{0}+\sum_{m=1}^{M} a_{m} \prod_{k=1}^{K_{m}}\left[S_{k m}\left(x_{v(k, m)}-t_{k m}\right)\right]
$$

dimana :

$a_{0} \quad=$ Koefisien konstanta dari basis fungsi $\beta_{0}$

$a_{m} \quad=$ Koefisien dari basis fungsi ke- $m$

$M \quad$ = Banyaknya fungsi basis

$K_{m} \quad=$ Derajat Interaksi

$t_{k m}=$ Nilai knot dari variabel prediktor

$x_{v(k, m)}=$ Variabel prediktor

$S_{k m} \quad=$ Nilainya 1 atau -1 jika berada di sebelah kanan atau kiri titik knot.

Untuk memenuhi konsep parsemoni (model sederhana) dilakukan backward stepwise yaitu memilih fungsi basis yang dihasilkan dari forward stepwise dengan meminimumkan nilai Generalized Cross Validation (GCV) sebagai berikut :

$$
\operatorname{LOF}\left(\hat{f}_{M}\right)=G C V
$$




$$
\begin{aligned}
& =\frac{\frac{1}{n} \sum_{i=1}^{n}\left[y_{i}-\hat{f}_{M}\left(x_{i}\right)\right]^{2}}{\left[1-\frac{C(M)}{n}\right]^{2}} \\
& =\frac{A S R}{\left[1-\frac{C(M)}{n}\right]^{2}}
\end{aligned}
$$

Dimana :

$$
\begin{array}{ll}
\hat{f}_{M}\left(x_{i}\right) & =\text { Taksiran/prediksi } y_{i} \\
n & =\text { Jumlah data } \\
x_{i} & =\text { Variabel prediktor } \\
y_{i} & =\text { Variabel respon } \\
\text { LOF } & =\text { Loss of funtion } \\
\text { ASR } & =\frac{1}{n} \sum_{i=1}^{n}\left[y_{i}-\hat{f}_{M}\left(x_{i}\right)\right]^{2} \\
C(M) & =\text { Trace }\left[\mathbf{B}\left(\mathbf{B}^{T} \mathbf{B}\right)^{-1} \mathbf{B}^{T}\right]+1 \\
\mathbf{B} & =\text { Matriks Basis Fungsi }
\end{array}
$$

\section{METODE PENELITIAN}

Data yang digunakan dalam penelitian ini adalah data sekunder yang diperoleh dari Badan Pusat Statistik (BPS) Provinsi Maluku dan Maluku Utara tahun 2018. Adapun variabel yang digunakan dalam penelitian ini terdiri atas variabel respon dan variabel prediktor. Variabel respon yang digunakan yaitu presentasi penduduk miskin $(y)$ dan variabel prediktor yang digunakan yaitu persentase luas lantai rumah $\left(x_{1}\right)$, persentase rumah tangga yang menggunakan jenis atap (jerami/ijuk/daun rumbia) $\left(x_{2}\right)$, persentase fasilitas tempat buang air besar $\left(x_{3}\right)$, persentase tempat rumah tangga yang tidak menggunakan dinding tembok $\left(x_{4}\right)$, persentase rumah tangga yang tidak memiliki fasilitas air minum $\left(x_{5}\right)$, persentase fasilitas penerangan yang digunakan $\left(x_{6}\right)$, persentase penggunaan kayu bakar untuk memasak $\left(x_{7}\right)$ persentase frekuensi makan dalam sehari $\left(x_{8}\right)$, persentase kebiasaan membeli daging/ayam/susu $\left(x_{9}\right)$, persentase penduduk yang sakit tetapi tidak berobat karena tidak memiliki biaya untuk berobat $\left(x_{10}\right)$, persentase lapangan pekerjaan kepala rumah tangga $\left(x_{11}\right)$ dan persentase pendidikan terakhir kepala keluarga yang tidak/belum pernah sekolah $\left(x_{12}\right)$, serta persentase kepemilikan aset $\left(x_{13}\right)$.

\section{HASIL DAN PEMBAHASAN}

\subsection{Gambaran Umum Kemiskinan di Provinsi Maluku dan Maluku Utara.}

Kemiskinan merupakan suatu kondisi dimana seseorang tidak mampu untuk memenuhi kebutuhan dasarnya seperti sandang, pangan, pendidikan dan kesehatan yang layak. Persentase kemiskinan diperoleh dari persentase penduduk yang berada dibawah garis kemiskinan. Dimana garis kemiskinan merupakan pejumlahan dari garis kemiskinan makanan (GKM) dan garis kemiskinan non makanan (GKNM). Adapun persentase penduduk miskin di Provinsi Maluku dan Maluku Utara dapat dilihat pada gambar berikut.

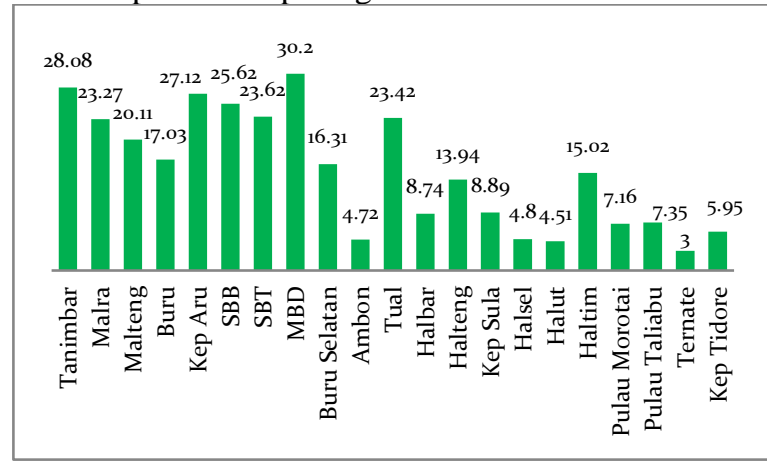

Gambar 1. Diagram Persentase Penduduk Miskin di Provinsi Maluku dan Maluku Utara

Berdasarkan gambar diatas, dapat ditunjukkan bahwa terdapat 21 Kabupaten/Kota di Provinsi Maluku dan Maluku Utara. Kabupaten/Kota yang memiliki persentase penduduk miskin tertinggi yaitu Kabupaten Maluku Barat Daya (MBD) dengan persentase sebesar 30.2\%. Selanjutnya Kepulaun Tanimbar dengan persentase sebesar 28.08\%, Kepulauan Aru sebesar 27.12\% serta Seram Bagian Barat (SBB) dan Seram Bagian Timur (SBT) sebesar 25.62\%. Selanjutnya Kabupaten/Kota yang memiliki persentase penduduk miskin terendah yaitu Kota Ternate dengan persentase sebesar 3\%. Selanjutnya Halmahera Utara dengan persentase sebesar $4.51 \%$, Ambon dengan persentase sebesar $4.72 \%$, Halmahera Selatan dengan persentase sebesar $4.8 \%$ dan Tidore Kepulauan dengan persentase sebesar $5.95 \%$.

\subsection{Pemodelan Faktor-faktor yang Mempengaruhi Penduduk Miskin di Provinsi Maluku dan Maluku Utara Menggunakan MARS}

Pemodelan faktor-faktor yang mempengaruhi kemiskinan di Provinsi Maluku dan Maluku Utara dengan pendekatan metode MARS dilakukan dengan mengkombinasikan banyaknya basis function (BF), maximum interaction (MI) dan minimum number of observaion (MO). Banyaknya BF yang digunakan adalah 2 sampai dengan 4 kali dari banyaknya variabel penelitian. MI yang digunakan adalah 1,2, atau 3 dengan pertimbangan jika lebih dari 3 akan menghasilkan model yang sangat kompleks. Jarak minimum antar knot atau observasi minimum (MO) antar knot yang 
digunakan adalah 0,1,2, atau 3. Langkah selanjutnya yaitu menuntukan model MARS berdasarkan nilai GCV minimum. Namun bila nilai GCV bernilai sama maka dapat dilihat pada model yang memiliki ketetapan klasifikasi terbesar.

Tabel 1. Hasil Seleksi Model MARS

\begin{tabular}{|c|c|c|c|c|}
\hline No & BF & MI & MO & GCV \\
\hline 1. & 26 & 1 & 0 & 0.1842 \\
\hline 2. & 26 & 1 & 1 & 0.1844 \\
\hline 3. & 26 & 1 & 2 & 0.1843 \\
\hline 4. & 26 & 1 & 3 & 0.1840 \\
\hline 5. & 26 & 2 & 0 & 0.1830 \\
\hline 6. & 26 & 2 & 1 & 0.1821 \\
\hline 7. & 26 & 2 & 2 & 0.1812 \\
\hline 8. & 26 & 2 & 3 & 0.1825 \\
\hline 9. & 26 & 3 & 0 & 0.1832 \\
\hline 10. & 26 & 3 & 1 & 0.1784 \\
\hline 11. & 26 & 3 & 2 & 0.1788 \\
\hline 12. & 26 & 3 & 3 & 0.1763 \\
\hline 13. & 39 & 1 & 0 & 0.1836 \\
\hline 14. & 39 & 1 & 1 & 0.1845 \\
\hline 15. & 39 & 1 & 2 & 0.1829 \\
\hline 16. & 39 & 1 & 3 & 0.1834 \\
\hline 17. & 39 & 2 & 0 & 0.1875 \\
\hline 18. & 39 & 2 & 1 & 0.1856 \\
\hline 19. & 39 & 2 & 2 & 0.1845 \\
\hline 20. & 39 & 2 & 3 & 0.1823 \\
\hline 21. & 39 & 3 & 0 & 0.1730 \\
\hline 22. & 39 & 3 & 1 & 0.1728 \\
\hline 23. & 39 & 3 & 2 & 0.1345 \\
\hline 24. & 39 & 3 & 3 & 0.1737 \\
\hline 25. & 52 & 1 & 0 & 0.1823 \\
\hline 26. & 52 & 1 & 1 & 0.1834 \\
\hline 27. & 52 & 1 & 2 & 0.1842 \\
\hline 28. & 52 & 1 & 3 & 0.1833 \\
\hline 29. & 52 & 2 & 0 & 0.1838 \\
\hline 30. & 52 & 2 & 1 & 0.1841 \\
\hline 31. & 52 & 2 & 2 & 0.1839 \\
\hline 32. & 52 & 2 & 3 & 0.1844 \\
\hline 33. & 52 & 3 & 0 & 0.1767 \\
\hline 34. & 52 & 3 & 1 & 0.1781 \\
\hline 35. & 52 & 3 & 2 & 0.1783 \\
\hline 36. & 52 & 3 & 3 & 0.1788 \\
\hline
\end{tabular}

Berdasarkan Tabel 1 di atas, diperoleh kriteria pemilihan model terbaik pada MARS yaitu dengan menggunakan $\mathrm{BF}=39, \mathrm{MI}=3$ dan $\mathrm{MO}=1$ dengan bentuk model.

$$
\begin{aligned}
\hat{f}(x)= & -0.125+0.128 B F_{1}-0.027 B F_{3}+0.035 B F_{4}+0.477 B \\
& +0.453 B F_{9}+0.875 B F_{13}
\end{aligned}
$$

dengan :

$$
\begin{aligned}
& B F_{1}=\max \left(0, x_{11}-42.215\right) ; \\
& B F_{3}=\max \left(0.634+x_{4}\right) ; \\
& B F_{4}=\max \left(0, x_{6}+45.211\right) ;
\end{aligned}
$$

$$
\begin{aligned}
& B F_{6}=\max \left(0,0.721-x_{7}\right) ; \\
& B F_{7}=\max \left(0, x_{4}-39.785\right) ; B F_{3} \\
& B F_{8}=\max \left(0, x_{10}+67.962\right) ; \\
& B F_{9}=\max \left(0, x_{7}-65.743\right) ; B F_{6} \\
& B F_{11}=\max \left(0, x_{11}-73.218\right) ; \\
& B F_{12}=\max \left(0, x_{7}-67.115\right) ; B F_{6} \\
& B F_{13}=\max \left(0,71.435+x_{12}\right) ;
\end{aligned}
$$

Berdasarkan model tersebut, diketahui terdapat 7 variabel prediktor yang mempengaruhi banyaknya penduduk miskin di Provinsi Maluku dan Maluku Utara. Intresprtasi model MARS hampir sama untuk semua basis fungsi, misalnya untuk $\mathrm{BF}_{1}$ adalah

$$
B F_{1}=\max \left(0, x_{11}-42.215\right)
$$

Artinya, koefisien $\mathrm{BF}_{1}$ akan bermakna jika nilai $x_{11}$ Lebih besar dari 42.215. Maka setiap kenaikan satu fungsi basis $\left(\mathrm{BF}_{1}\right)$ dapat meningkatkan persentase penduduk miskin di Provinsi Maluku dan Maluku Utara sebesar 0.128 persen, dengan persentase lapangan pekerjaan kepala rumah tangga lebih dari 42.215 persen.

Intresprprestsi lebih mudah dimengerti atau dipahami dengan menggunakan nilai odds ratio. Nilai odd ratio diperoleh dengan rumus $e^{a_{m}}$, dimana $a_{m}$ adalah koefisien dari fungsi basis ke- $m$. Nilai odds ratio masing-masing fungsi basis ditunjukkan pada Tabel 2 berikut berikut.

Tabel 2. Nilai odds ratio masing-masing fungsi

\begin{tabular}{|c|c|c|c|}
\hline No & Variabel & $\begin{array}{c}\text { Tingkat } \\
\text { Kepentingan }\end{array}$ & $\overline{-}$ \\
\hline 1. & $\begin{array}{l}\text { sentase } \\
\text { angan pekerjaan }\end{array}$ & $100 \%$ & 0.128 \\
\hline
\end{tabular}
basis

\begin{tabular}{ccc}
\hline BF & Koefisien & Odds Ratio \\
\hline $\mathrm{BF}_{1}$ & 0.128 & 1.021 \\
$\mathrm{BF}_{3}$ & -0.027 & 1.112 \\
$\mathrm{BF}_{4}$ & 0.035 & 1.123 \\
$\mathrm{BF}_{6}$ & 0.477 & 1.014 \\
$\mathrm{BF}_{9}$ & 0.453 & 1.073 \\
$\mathrm{BF}_{13}$ & 0.875 & 1.105 \\
\hline
\end{tabular}

Intrepretasi nilai odds ratio dari Tabel 2 di atas yaitu untuk $\mathrm{BF}_{1}$ mempunyai nilai odds ratio sebesar 1.021. Hal ini menunjukkan bahwa persentase kepala keluarga yang tidak mempunyai pekerjaan tetap, cinderug akan meningkatkan persentase penduduk miskin sebesar 1.021 kali jika dibandingkan dengan kepala keluarga yang memiliki pekerjaan tetap.

Tabel 3. Variabel Prediktor Mempengaruhi Pengurangan Nilai GCV 


\begin{tabular}{|c|c|c|c|}
\hline No & Variabel & $\begin{array}{c}\text { Tingkat } \\
\text { Kepentingan }\end{array}$ & - \\
\hline & $\begin{array}{l}\text { kepala rumah } \\
\text { tangga }\left(x_{11}\right)\end{array}$ & & \\
\hline 2. & $\begin{array}{l}\text { Persentase rumah } \\
\text { tangga yang } \\
\text { menggunakan jenis } \\
\text { atap (jerami / ijuk / } \\
\text { daun rumbia) }\left(x_{2}\right)\end{array}$ & $95 \%$ & 0.127 \\
\hline & $\begin{array}{l}\text { Persentase rumah } \\
\text { tangga yang tidak }\end{array}$ & & \\
\hline 3. & $\begin{array}{l}\text { menggunakan } \\
\text { dinding tembok } \\
\left(x_{4}\right)\end{array}$ & $95 \%$ & 0.127 \\
\hline 4. & $\begin{array}{l}\text { Persentase fasilitas } \\
\text { penerangan yang } \\
\text { digunakan }\left(x_{6}\right)\end{array}$ & $93 \%$ & 0.126 \\
\hline 5. & $\begin{array}{l}\text { Persentase } \\
\text { penduduk yang } \\
\text { sakit tetapi tidak } \\
\text { berobat karena } \\
\text { tidak memiliki } \\
\text { biaya untuk } \\
\text { berobat }\left(x_{10}\right)\end{array}$ & $80 \%$ & 0.125 \\
\hline 6. & $\begin{array}{l}\text { Persentase } \\
\text { pendidikan terakhir } \\
\text { kepala keluarga } \\
\text { yang tidak/belum } \\
\text { pernah sekolah } \\
\left(x_{12}\right)\end{array}$ & $62 \%$ & 0.123 \\
\hline 7. & $\begin{array}{l}\text { Persentase rumah } \\
\text { tangga yang tidak } \\
\text { memiliki fasilitas } \\
\text { air minum }\left(x_{5}\right)\end{array}$ & $50 \%$ & 0.122 \\
\hline 8. & $\begin{array}{l}\text { Persentase luas } \\
\text { lantai rumah }\left(x_{1}\right)\end{array}$ & $0 \%$ & 0.120 \\
\hline 9. & $\begin{array}{l}\text { Persentase rumah } \\
\text { tangga yang } \\
\text { memiliki fasilitas } \\
\text { tempat buang air } \\
\text { besar }\left(x_{3}\right)\end{array}$ & $0 \%$ & 0.120 \\
\hline 10. & $\begin{array}{l}\text { Persentase } \\
\text { penggunaan kayu } \\
\text { bakar untuk } \\
\text { memasak }\left(x_{7}\right)\end{array}$ & $0 \%$ & 0.120 \\
\hline 11. & $\begin{array}{l}\text { Persentase } \\
\text { frekuensi makan } \\
\text { dalam sehari }\left(x_{8}\right)\end{array}$ & $0 \%$ & 0.120 \\
\hline
\end{tabular}

Persentase

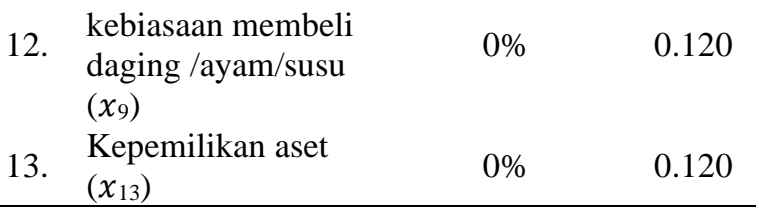

Berdasarkan Tabel 3 di atas, dapat dilihat bahwa variabel persentase lapangan pekerjaan pada model MARS memiliki tingkat kepentingan sebesar $100 \%$. Kemudian diikuti secara berturutturut oleh persentase rumah tangga yang menggunakan jenis atap (jerami/ijuk/daun rumbia), persentase rumah tanggayang tidak menggunakan dinding tembok, persentase fasilitas penerangan yang digunakan, persentase penduduk yang sakit tetapi tidak berobat karena tidak memiliki biaya untuk berobat serta persentase rumah tangga yang tidak memiliki fasilitas air minum. Kontribusi variabel yang berpengaruh pada model adalah secara berturut-turut yaitu sebesar 95\%, 95\%, 93\%, $80 \%$, 62\%, dan 50\%. Selanjutna dapat juga dilihat bahwa terdapat 6 variabel memiliki tingak kepentingan sebesar $0 \%$, yang berarti bahwa variabel-variabel tersebut tidak masuk dalam model karena sudah terwakili oleh variabelvariabel yang masukdalam model MARS.

Nilai minus GCV menunjukan bahwa apabila variabel persentase lapangan pekerjaan kepala rumah tangga $\left(x_{11}\right)$ dimasukan dalam model, maka nilai GCV akan berkurang sebesar 0.128. Apabila persentase rumah tangga yang menggunakan jenis atap (jerami/ijuk/daun rumbia) $\left(x_{2}\right)$ dimasukan dalam model, maka nilai GCV akan berkurang sebesar 0.127. Apabila persentase rumah tangga yang tidak menggunakan dinding tembok $\left(x_{4}\right)$ dimasukan dalam model, maka nilai GCV akan berkurang sebesar 0.127. Apabila persentase fasilitas penerangan yang digunakan $\left(x_{6}\right)$ dimasukan dalam model, maka nilai GCV akan berkurang sebesar 0.126. Apabila persentase penduduk yang sakit tetapi tidak berobat karena tidak memiliki biaya untuk berobat $\left(x_{10}\right)$ dimasukan dalam model, maka nilai GCV akan berkurang sebesar 0.125. Apabila persentase pendidikan terakhir kepala keluarga yang tidak/belum pernah sekolah $\left(x_{12}\right)$ dimasukan dalam model, maka nilai GCV akan berkurang sebesar 0.123 . Apabila persentase rumah tangga yang tidak memiliki fasilitas air minum $\left(x_{5}\right)$ dimasukan dalam model, maka nilai GCV akan berkurang sebesar 0.122. Kemudian jika variabel persentase luas lantai rumah $\left(x_{1}\right)$, persentase fasilitas tempat buang air besar $\left(x_{3}\right)$, persentase penggunaan kayu bakar untuk memasak $\left(x_{7}\right)$ persentase frekuensi makan dalam sehari $\left(x_{8}\right)$, persentase kebiasaan membeli daging/ayam/susu $\left(x_{9}\right)$, dan persentase kepemilikan aset $\left(x_{13}\right)$ dimasukan dalam model, maka nilai GCV akan berkurang sebesar 0.120.

Berdasarkan pemodelan yang telah dilakukan, maka diperoleh 7 variabel prediktor yang berpengaruh secara signifikan terhadap kemiskinan di Provinsi Maluku dan Maluku Utara yaitu 
variabel persntase lapangan pekerjaan kepala rumah tangga $\left(x_{11}\right)$, persentase rumah tangga yang menggunakan jenis atap (jerami/ijuk/daun rumbia) $\left(x_{2}\right)$, persentase rumah tangga yang tidak menggunakan dinding tembok $\left(x_{4}\right)$, persentase fasilitas penerangan yang digunakan $\left(x_{6}\right)$, persentase penduduk yang sakit tetapi tidak berobat karena tidak memiliki biaya untuk berobat $\left(x_{10}\right)$, persentase pendidikan terakhir kepala keluarga yang tidak/belum pernah sekolah $\left(x_{12}\right)$ dan persentase rumah tangga yang tidak memiliki fasilitas air minum $\left(x_{5}\right)$.

Berdasarkan hasil ini maka pemerintah Provinsi Maluku dan Maluku Utara perlu mengabil langkah cepat dalam menyelesaikan masalah kemiskinan di daerah masing-masing.

\section{KESIMPULAN DAN SARAN}

Berdasarkan hasil dan pembahasan, maka diperoleh kesimpulan yaitu model MARS terbaik diperoleh dengan kombinasi $\mathrm{BF}=39, \mathrm{MI}=3$ dan $\mathrm{MO}=1$ dengan GCV minimum sebesar 0.1728 . Adapun variabel yang berpengaruh secara signifikan terhadap kemiskinin di Provinsi Maluku dan Maluku Utara yaitu variabel persntase lapangan pekerjaan kepala rumah tangga $\left(x_{11}\right)$, persentase rumah tangga yang menggunakan jenis atap (jerami/ijuk/daun rumbia) $\left(x_{2}\right)$, persentase rumah tangga yang tidak menggunakan dinding tembok $\left(x_{4}\right)$, persentase fasilitas penerangan yang digunakan $\left(x_{6}\right)$, persentase penduduk yang sakit tetapi tidak berobat karena tidak memiliki biaya untuk berobat $\left(x_{10}\right)$, persentase pendidikan terakhir kepala keluarga yang tidak/belum pernah sekolah $\left(x_{12}\right)$ dan persentase rumah tangga yang tidak memiliki fasilitas air minum $\left(x_{5}\right)$. Selanjutnya direkomendasikan kepada pemerintah Provinsi Maluku dan Maluku Utara untuk mengevaluasi program penuntasan kemiskinan dan mengambil kebijakan, agar masalah kemiskinan dapat diselesaikan.

Saran untuk penelitian selanjutya yaitu dalam pembentukan model MARS bisa dilakukan pembagian data dalam bentuk training dan testing. Pembagian ini diharapkan bisa memperoleh model terbaik yang benar-benar bisa mewakili kasus yang sedang diteliti.

\section{DAFTAR PUSTAKA}

Badan Pusat Statistik Provinsi Maluku. 2019. Provinsi Maluku Dalam Angka 2019. Ambon, Maluku: BPS Provinsi Maluku. Diakses dari https://maluku.bps.go.id/publication/2019/08/ $\underline{16 / 1491 f d 5 b 45 f a 85 a 8 a 94 b 79 b 7}$
Badan Pusat Statistik Provinsi Maluku Utara. 2019. Provinsi Maluku Dalam Angka 2019. Ambon, Maluku:BPS Provinsi Maluku Utara. Diakses dari https://malut.bps.go.id/publication/2019/08/1 6/b5f8974ef9f7a17b069fb291

Bilski, P. 2020. Analysis of the Ensemble of Regression Algorithms for the Analog Parametric Identification. Measurement: Journal of the International Measurement Confederation. Diakses dari https://doi.org/10.1016/j.measurement2020.1 $\underline{07829}$

Budiantara, I., \& Wulandari, I. 2014. Analisis Faktor-Faktor yang Mempengaruhi Persentase Penduduk Miskin dan Pengeluaran Perkapita Makanan di Jawa Timur Menggunakan Regresi Nonparametrik Birespon Spline. Jurnal Sains Dan Seni ITS, 3(1). Surabaya.

Dedefo, M. G., Abate, S. K., Ejeta, B. M., \& Korsa, A. T. 2020. Predictors of poor glycemic control and level of glycemic control among diabetic patients in west Ethiopia. Annals of Medicine and Surgery, 55 (January), 238-243. Diakses dari https://doi.org/10.1016/j.amsu.2020.04.034

Friedman, J.H. 1991. Multivariate Adaptive Regression Spline (With Discussion),The Annals of Statistics, Vol. 19, hal. 1-141.

Jurnal Riset dan Aplikasi Matematika. Vol. 4 No. 1 (2020) pp. 50-62. DOI: 10.26740/jram.v4n1.p51-62

Kishartini, Diah Safitri, Dwi Ispriyanti. 2014. Multivariate Adaptive Regression Splines (MARS) Untuk Klasifikasi Status Kerja Di Kabupaten Demak. Jurnal Gaussian, Volume 3, Nomor 4, Tahun 2014, Halaman 711 718. Diakses dari http://ejournals1.undip.ac.id/index.php/gaussian

Leathwick, J. R., Elith, J., \& Hastie, T. 2006. Comparative Performance of Generalized Additive Models and Multivariate Adaptive Regression Splines for Statistical Modelling of Species Distributions. Ecological Modelling, 199(2), 188-196. Diakses dari https://doi.org/10.1016/j.ecolmodel.2006.05.0 22

Matdoan, M. Y. B. W. Otok, R.M. Atok. 2020. Modeling of Quantile Regression to Know the Factors Affecting the High Spread Api Malaria in Indonesia. Jurnal Matematika, Statistika dan Komputasi, 16(3), 417. https://doi.org/10.20956/jmsk.v16i3.8970 
Matdoan, M. Y, B. W. Otok, R.M. Atok. 2020. Estimasi Parameter Regresi Quantil dengan Regresi Robust Least Trimmed Square (LTS) (Studi Kasus : Faktor-Faktor yang Mempengaruhi Penyebaran Penyakit Malaria di Indonesia).
Nuraziza Arfan dan I Nyoman Budiantara. 2014. Pendekatan Spline untuk Estimasi Kurva Regresi Nonparametrik (Studi Kasus pada Data Angka Kematian Maternal di Jawa Timur). Jurnal sains dan seni pomits Vol. 3, No.1, (2014) 2337-3520. 